\title{
On Literary Reviews Tried and Untried
}

\section{John D.Erickson}

What justifies the creation of a literary review, one in particular by and for graduate students of language and literature? I feel the urge to say that a review publishes its justification with its first number. The mere and mighty fact of existence provides its reason. So, when all market evaluations contradict each other and all auguries spell confusion, go to press to find the answer.

On the other hand, seeing that the death ratio of new reviews comes uncomfortably close to the number founded, perhaps a concrete need should express itself before putting it on the line. It helps to know a new review will reach a readership that will respond to the editorial attitude of the review. As Charles Angoff, editor of The Literary Review, once put it, ". . . the heart of a little magazine is to be sought in its attitude." So far as graduate students are concerned, I doubt that established or professional language and literature reviews answer fully their need for a forum dealing with the particular problems that interest them, nor do they answer the need for a review a student might feel he has a chance to publish in. The attitude of established reviews generally develops around the needs of professional scholars and readers who have accumulated many grey hairs and facts, a little significant knowledge and often an inflated sense of their own importance. Established reviews to varying degrees serve as outlets for intelligent scholarly and humanistic studies, dispensers of historical-biographical and pedigogical information, club organs and ego-boosters. The attitude of these journals, along with other factors I shall mention presently, does (and sometimes should) discourage the graduate student from trying to publish in them. 
Let me relate my experience in founding a review in 1961. As a graduate student myse1f, I felt that L'Esprit Créateur, though not a graduate literary review, might open its pages to good graduate student work that would hold its own with that of seasoned scholars. I entertained a modest vision of the journal becoming a voice not only for the old and tried (people, methods and ideas) but also for the young and untried. My expectations have been fulfilled only partially. Numerous young scholars have published in L'Esprit Créateur but not an impressive number of graduate students. The reasons may be obvious.

Competition to publish in a good professional review is usually severe. It has caused us to decline a fair proportion of graduate articles submitted. A graduate student enters the lists against a formidable field of opponents, most well established in their specialty who by way of having become "established" have spent years of painstaking research and writing (they can show you drawers full of it), years of learning the ins and outs of various reviews and editors, what they want, what they' 11 take, how far they' 11 go, etc.

Another problem militating against graduate students publishing in professional reviews is that such reviews often seem rather redoutable from the vantage point of a university classroom. Or, on the other hand, their very professionalism turns away the gifted student who feels he has something new or different to say. A brief year ago, Prof. Wąllace Fowlie referred to an incident involving some young critics from an eastern school who approached him for advice about starting a new review. Their justification rested on the premise that such "staid" reviews as Yale French Studies and L'Esprit Créateur, which dominate the field of French literary studies in the United States, so the story goes, are unresponsive to young critics who throw new and startling light into dreary corners. Eh ben: Despite the effort I have made in times past to attract just such revolutionary ideas, not one of those young critics has to my knowledge ever submitted an article or review to the journal! And probably won't, for the simple test for unresponsiveness (submission of an article) matters less than the premise, which, after all, comes from the deep- 
seated desire for a review unfettered by anything resembling tradition. Truth it is, as discouraging as it might be, not that such reviews as ours dissuade new writers and new ideas but that, being "established," they inhibit them. By the mere fact of longevity (a decade equals a century in the hypertensive world of reviews) and the telltale tracks of a few well-known writers left in the drifts of its pages--a review qualifies as "established". I guess. The thing about being avantgarde is that nothing can be it all its life.

The graduate literary review offers several down-toearth possibilities. On the positive side, (1) it would provide a proper medium for the stage in research and writing that a graduate student has reached and, by so doing, (2) it would provide an outlet to that need to write (which should function as our second nature in graduate school) and a chance to go through the hot and heavy time of vision and revision needed for the printed word. (3) Finally, it would encourage a young writer to go on, by the very real fact of allowing him the luxury of an article accepted and printed.

Furthermore, the graduate review promises, looking at it negatively, (1) to obviate the expense of energy going into writing for professional reviews that could drain the graduate student as well as divert him from work immediately at hand, (2) to do away with the apprehension and disappointment in submitting to a professional review something that stands little chance of making it, (3) to make less common (I speak with the self-interestedness of an "established" editor) the submission to established reviews of articles whose style and content have not yet matured or do not aim for the appropriate readers but which nonetheless merit publication.

Little if anything exists at the moment between written class work and the professional reviews. A graduate student who feels he has sufficient background, skill and courage to reach for the open market and surmount the unfair advantage of "established" writers should receive wholehearted encouragement. But he should also ask himself whether he has prepared well enough the ground he leaps from. A graduate review 
makes an excellent trampoline for such leaps. Pascal, though not the first or last to do so, has spoken of the need to go through all the intermediate motions as we develop. It behooves us little to omit walking, in order to run early, if we run on unformed legs. The advantages mentioned earlier of a graduate review are but the most obvious ones. Other exciting possibilities arise as well in the contemplation of such an effort:

1. Robert Bly, editor of the Sixties, once criticized American little magazines as being pointless. "Instead of trying to bring a new sort of writing to birth, the editors just walk around with their eyes on the ground, looking for apples already fallen." The graduate review promises a new sort of writing. Seeing that it is a review by students for students, its attitude could allow remarkable flexibility. The possibilities inherent in experimenting with form and content are limited only by cost, imagination and the Postmaster General. Though I have referred essentially to critical writing, I assume that such a review could serve (as Chimères already does) as a medium for creative writing in a foreign language. In the United States, reviews accepting creative work in the French language are rare. One rather longlived one--1e Bayou--met its demise not long ago.

2. A graduate review could serve as a forum for the exchange of creative and interpretive techniques and ideas between students from different schools or even different countries. How much do students in American graduate schools know about attitudes of students at foreign universities? For that matter how much do graduate students know about what goes on in graduate departments at other schools?

3. Such a review could further specific projects such as scholarship drives and contests, or function generally as a public voice for graduate departments. Immense value lies in getting to know the makeup of a particular graduate department through its review--what better way than through the capabilities and interests of contributing students? Also, such a review might adapt well to particular class needs (for example, certain bibliographical material developed by students in a graduate seminar at the University of Kansas and pub- 
lished in Chimères has proved exceedingly useful to faculty and students alike).

The experience of establishing a graduate review bids fair to be not only enlightening but absorbing. Assuming the editorial staff to function as a cooperative effort that is not impossibly unwieldy in numbers (a danger even reviews begun with the most abundant resources and professional advice sometimes fail to recognize in time--a major midwest literary review in the early sixties foundered for two years in such a way), but in which a fair proportion of students will eventually take part, the result is hardfound knowledge of what goes into a review between the rough manuscript and the finished page, knowledge which will be of inestimable help later on.

I have merely gestured in the direction of a few possible roads a graduate literary review might take. The big danger is that a great deal of effort be wasted on something that turns out meaningless. To prevent it from turning into a mere grab-bag of information and repository for uninspired mechanical research, it is more important than ever to keep our eyes steadily on what we are and what we must remain as students of language and literature and the human condition. We are humanists, and such a review foretokens little if it fails to put above all else human concerns. In our time, when there prevails, as William Arrowsmith puts it, an "incredible lack of human concern among humanists," a graduate review would be better unborn than that it deal with trivia. But we can be encouraged by the fact that just such a review has a better chance of keeping its options open than have many professional reviews that subserve incredibly narrow and petty ends. Instead of contentedly sticking to the we11-traveled roads of review writing today, then, the graduate review gives promise of striking out on roads as yet untaken. No less a spirit than Baudelaire would find that the strongest of justifications. 